\title{
Beyond local (in)capacity: analyzing the implementation of a federally induced urban policy in Brazil
}

\section{Fernanda Lima-Silva ${ }^{1}$ Maria Rita Loureiro ${ }^{1}$ \\ ${ }^{1}$ Fundação Getúlio Vargas - Escola de Administração de Empresas de São Paulo - SP, Brasil}

The article analyzes the capacity production of a Brazilian urban policy (Program of Acceleration of Growth - Slum Upgrading, PAC-UAP), whose implementation flaws are commonly associated with municipal governments shortcomings, even though its interventions involve a multiplicity of actors. Three analytical and empirical aspects are considered: (i) the need to expand knowledge on state capacity in policies implemented by a network of actors; (ii) the relevance of the debate of policy capacity, which refers to the ability of reaching the expected results in a specific public policy; (iii) and the demand to explore federally induced public policies in federations marked by heterogeneous subnational entities. Methodologically, the work develops a case study, complemented by documental analysis and interviews with key stakeholders. The research corroborates studies that emphasize that municipal problems affected the production capacity of PACUAP, particularly the lack of adequate human and financial resources. On the other hand, this study innovates when considering that the municipality is, in fact, the node of a network of actors, whose (in)capacity also affects the implementation. Therefore, it might not be possible to attribute only to the municipality the (in)success of this program. The article also reinforces the importance of incorporating organizational and systemic dimensions as explanatory elements, whose challenges can be potentiated when a program design is not adequate to the intrinsic characteristics of a certain public policy.

Keywords: policy capacity, slum upgrading, Brazil

The research that originated the present study was financed by the Coordenação de Aperfeiçoamento de Pessoal de Nivel Superior - Brasil (CAPES) - Finance Code 001". We thank the organizers and participants at the International Workshop on Building Capable States for Development in Latin America, which was carried out in São Paulo (December 2018), for their valuable feedback and suggestions. 


\section{Além da (in)capacidade local: analisando a implementação de uma política urbana induzida pelo Governo Federal no Brasil}

O artigo analisa a capacidade de produção de uma política urbana brasileira (Programa de Aceleração do Crescimento - Urbanização de Assentamentos Precários, PAC-UAP), cujas falhas de implementação são comumente associadas a deficiências dos governos municipais, embora suas intervenções envolvam vários atores. Três aspectos analíticos e empíricos são considerados: (i) a necessidade de expandir o conhecimento sobre capacidade estatal em políticas implementadas por uma rede de atores; (ii) a relevância do debate sobre capacidade de produção de políticas públicas, que se refere à capacidade de alcançar os resultados esperados em uma política pública específica; (iii) e a demanda por compreender políticas públicas induzidas pelo governo federal em federações marcadas pela heterogeneidade entre governos locais. Metodologicamente, o trabalho desenvolve um estudo de caso, complementado por análise documental e entrevistas com atores-chave. A pesquisa corrobora estudos que enfatizam que os problemas municipais afetaram a capacidade de produção do PAC-UAP, particularmente a falta de recursos humanos e financeiros adequados. Por outro lado, inova ao considerar que o município é, na verdade, o nó de uma rede de atores, cuja (in)capacidade também afeta a implementação. Portanto, parece não ser possível atribuir apenas ao município o (in)sucesso desse programa. $\mathrm{O}$ artigo também reforça a importância de incorporar dimensões organizacionais e sistêmicas como elementos explicativos, cujos desafios podem ser potencializados quando o desenho de um programa não é adequado às características intrínsecas de uma determinada política pública.

Palavras-chave: capacidade de produção de políticas públicas, urbanização de favelas, Brasil

\section{Más allá de la (in)capacidad local: análisis de la implementación de una política urbana inducida por el gobierno federal en Brasil}

El artículo analiza la capacidad de producción de una política urbana brasileña (Programa de Aceleración del Crecimiento - Mejoramiento de asentamientos precarios, PAC-UAP), cuyos problemas de implementación son comúnmente asociados con las deficiencias de los gobiernos municipales, a pesar de que sus intervenciones involucran varios actores. Se consideran tres aspectos analíticos y empíricos: (i) la necesidad de ampliar el conocimiento sobre la capacidad estatal en las políticas implementadas por una red de actores; (ii) la relevancia del debate sobre la capacidad de producción de políticas públicas, que se refiere a la capacidad de alcanzar los resultados esperados en una política pública específica; (iii) y la demanda de explorar políticas públicas inducidas por el gobierno federal en federaciones marcadas por heterogeneidades entre los gobiernos locales. Metodológicamente, el trabajo desarrolla un estudio de caso, complementado con análisis documental y entrevistas con actores-llave. La investigación corrobora estudios que enfatizan que los problemas municipales afectaron la capacidad de producción de PAC-UAP, particularmente la falta de recursos humanos y financieros adecuados. Por otro lado, innova cuando se considera que el municipio es, de hecho, el nodo de una red de actores, cuya (in)capacidad también afecta la implementación. Por lo tanto, parece no ser posible atribuir solo al municipio el (in)éxito de este programa. El artículo también refuerza la importancia de incorporar dimensiones organizativas y sistémicas como elementos explicativos, cuyos desafíos pueden potenciarse cuando el diseño de un programa no es adecuado para las características intrínsecas de una determinada política pública.

Palabras clave: capacidad de producción de políticas, urbanización de asentamientos precarios, Brasil 


\section{Introduction}

One of the most fundamental notions in the study of public administration is the ability of a government to accomplish its goals. The literature and policymakers agree that governments with high levels of capacity are more equipped to produce policies that reach the planned outcomes. However, the debate of state capacity is centered on a concept that is marked by intense polysemy, which makes its conceptualization and operationalization problematic (GOMIDE et al., 2017; LINDVALL \& TEORELL, 2016; Cingolani, 2013; Kocher, 2010).

More recently, this debate gains a new perspective, with a renewed interest in the analysis and understanding of policy capacity, which refers to the ability of reaching the expected results in a specific public policy (WU et al., 2015; PAINTER \& PIERRE, 2005). The combination of the growing complexity of contemporary public policy problems, increasing participation of multiple stakeholders in the production of policies and high citizen expectations generates unprecedented challenges for governments' ability to design and implement effective public policies, requiring different sets of resources and competences at three different levels - individual, organizational and systemic (Wu et al., 2015). The usefulness of the nested-model of capacity created by these authors is clear, allowing an analysis in which levels are interdependent and different resources and abilities are taken into consideration.

Considering that the development of public policies are increasingly decentralized, frequently involving different levels and agencies of government as well as civil organizations and private companies, it is reasonable to argue that more comprehensive understanding of the capacity of all the relevant actors involved in policy implementation is required. The need to look at subnational entities' capacity becomes even more pressing in federative contexts that are characterized by local governments assuming the role of welfare providers (STOKER, 2011) and by high inequality among local governments (SAGUIN \& RAMESH, 2018; GRIN, 2016; SOUZA, 2002; FARAH, 2001).

Taking this into account, the literature in many federative countries has given privileged attention to local governments' capacity to implement federally induced policies. After all, successful shared and decentralized policies require that all the relevant agencies and levels of governments have the capacity to perform the essential required 
functions. Otherwise, "conferral of authority and responsibility in the absence of capacity is a recipe for failure" (SAGUIN \& RAMESH, 2018, p. 5).

In the present work we recognize the relevance of local governments' capacity to produce public policies. Notwithstanding, we argue that a more accurate understanding of policy capacity requires a broader perspective, including the capacity of other actors involved in the implementation process, as well as the characteristics of the public policy.

Empirically, this article will analyze the Program of Acceleration of Growth, specifically its modality of Slum Upgrading (hereinafter PAC-UAP). PAC-UAP was launched by the Brazilian federal government in 2007, representing a turning point in this area of public policy: it was the first time that a national program invested large sums of financial resources in slum upgrading, making it possible for local governments to broaden the scope and the complexity of the interventions (CARDOSO \& DENALDI, 2018; DENALDI et al., 2016; KLINTOWITZ, 2015).

This modality of the program has particular features that justify its choice as a case study. Firstly, even though PAC-UAP follows the Brazilian predominant federative arrangement, in which federal government elaborates, regulates and finances the program, while subnational governments implement them (ARRETCHE, 2012; ABRUCIO, 2005), in this modality of PAC, subnational governments were leading figures, assuming responsibility for the planning and development of the interventions. Secondly, its execution involved a myriad of governmental actors, such as the Ministry of Cities; the federal bank responsible for its operationalization, Caixa Econômica Federal; federal and other local government departments, such as social assistance, transportation and health; as well as societal actors, including social/housing movements, residents in the upgraded area and construction companies. Thirdly, besides the availability of financial resources and an intensive monitoring system by the federal government, many of PAC-UAP's interventions had implementation problems, facing delays and interruptions. The argument that justifies the low execution rates of this modality of the program often focuses on the feeble municipal capacity (CAMPANHONI, 2016; DENALDI et al., 2016; Denaldi \& Ferrara, 2017; Cardoso \& Denaldi, 2018; Petrarolli, 2015). However, as we will demonstrate in the present research, a more refined comprehension of its implementation results can only be achieved if other factors are taken into careful consideration. 
Methodologically, the work uses an approach based on the logic of instrumental case study, as proposed by Stake (1998), which allows the exploration of a research question that extrapolates one particular case. According to this author, in an instrumental logic, the case plays a supportive role that provides insights into an issue and facilitates our understanding of external interests. In his words, "the case still is looked at in depth, its contexts scrutinized and its ordinary activities detailed, but all because this helps pursue the external interest (STAKE, 1998, p. 445)"'.

This research also utilizes two other qualitative research techniques - documental analysis and interviews. Documental analysis was adopted as an initial research strategy and encompassed federal governmental publications that dealt specifically with PAC and PAC-UAP (BRASIL, 2010, 2014). The purpose was to understand in detail how this modality of the program was planned to operate, including its goals and actors involved. In addition, the researchers conducted interviews with public managers from the federal government, specifically the Ministry of Cities and Caixa Econômica Federal, and from the municipalities of Santo André and São Bernardo do Campo, both located in the metropolitan region of São Paulo. These cities had a history of slum upgrading from the 1980s onwards and developed several slum upgrading interventions within PAC-UAP. Furthermore, these municipalities are particularly interesting for the present analysis since they present different financial execution rates: in the first edition of PAC-UAP, São Bernardo achieved in average 80\%, while Santo André, less than 50\% (LIMA-SILVA, 2019). The interviews were conducted in 2018 and the respondents were chosen intentionally, considering their involvement with this modality of the program and access opportunities. To preserve their identity, the interviewees were named Interviewee A, B, $\mathrm{C}, \mathrm{D}, \mathrm{E}, \mathrm{F}$ and $\mathrm{G}$, as shown in Chart 1 . The interviews were made based on a semistructured script, and they were fully recorded and transcribed, facilitating their subsequent analysis.

Chart 1 - Identification of the interviewees per institution and role within PAC-UAP

\begin{tabular}{|c|c|c|}
\hline Interviewee & Institution* & Role \\
\hline A & Ministry of Cities & Coordination of housing policies \\
\hline B & Ministry of Cities & Coordination of slum upgrading programs \\
\hline C & $\begin{array}{c}\text { Santo André, São Bernardo do } \\
\text { Campo }\end{array}$ & $\begin{array}{c}\text { Coordination of slum-upgrading } \\
\text { interventions }\end{array}$ \\
\hline D & Santo André & Coordination of housing policies \\
\hline
\end{tabular}

REVISTA DO SERVIÇO PÚBLICO | Brasília 71 (special) 116-143 Oct. 2020 


\begin{tabular}{|c|c|c|}
\hline Interviewee & Institution* & Role \\
\hline E & Ministry of Cities & $\begin{array}{c}\text { Coordination of slum upgrading and } \\
\text { sewage programs }\end{array}$ \\
\hline F & Ministry of Cities & Technical assistance for housing policies \\
\hline G & Caixa Econômica Federal & $\begin{array}{c}\text { Civil servant, experience in slum } \\
\text { upgrading }\end{array}$ \\
\hline
\end{tabular}

Source: Elaborated by the authors.

*Respondents were not necessarily working with PAC-UAP at the time of the interview, but they were chosen because they had had working experience with this program's implementation.

The following text is structured in four parts. Firstly, considerations on local governments' capacity for public policy production in Brazil. Secondly, it is presented a brief trajectory of Brazilian social housing policy, focusing on interventions on slums and governmental capacity to develop them. Thirdly, PAC-UAP is described, followed by an analysis on its policy capacity. At last, final considerations are woven.

\section{Local capacity for (shared) policy production in Brazil}

The Brazilian Constitution of 1988 launched a highly decentralized federation, based on an expectation of democratization at the local level and increased effectiveness of government policies (FARAH, 2001; ABRUCIO, 2005). Nevertheless, in line with Saguin and Ramesh's (2018) argument that decentralization and governance are hardly pursued with consideration of capacity, a few years later, it became clear that most Brazilian municipal governments lacked resources and expertise, as well as administrative and managerial capacity, to execute those policies (ARRETCHE et al., 2012; GRIN, 2016).

This sensitive situation was partially tackled from the 1990s on with the emergence of federative coordination: the federal government designs and finances policies, while subnational governments implement them (ABRUCIO, 2005; ARRETCHE, 2012). In a country marked by socioeconomic and capacity inequalities among local governments, this shift in intergovernmental relations contributed to stimulating joint and articulated action between levels of government (ABRUCIO, 2005) and to reducing territorial inequalities in the access to public services and goods (ARRETCHE, 2012). Federative coordination also contributed to the improvement of local governments' capacity. 
Despite these advances, the heterogeneity of capacity among municipalities remains a significant challenge in the Brazilian Federation, appearing on the agenda of academics and professionals (GRIN, 2016; ARRETCHE et al, 2012; ARRETCHE, 2012; BRASIL, 2006). The literature indicates that even when a public policy is strongly induced by higher governments, its results and impacts in the course of institutions are not the same in subnational units (SOUZA, 2002; BICHIR, 2011). Consequently, the proper implementation of social and development policies, in a country that is highly decentralized administratively, is still viewed as dependent mainly on the strengthening of municipal management capacity (GRIN, 2016).

Recent studies have advanced on the understanding of the complexity involved in implementing federally induced policies in a heterogenous federations, aiming to complement the accumulated knowledge on the literature of federalism and municipal capacity in Brazil. Some have indicated that automatically associating policy results and capacity to the existence of local bureaucrats is an argument that needs to be refined. Cardoso and Marenco (2019) investigated if the quality of municipal bureaucracy affects economic inequality and concluded that training bureaucrats is more relevant than having a large number of public servants. Complementarily, Satyro et al. (2016) questioned if characteristics of municipal bureaucracy impact the results of the social assistance policy, concluding that this policy's implementation capacity did not rely on the existence of a stable and professionalized bureaucracy.

Other studies have illuminated broader aspects of the policy-making, highlighting relevant analytical dimensions to understand local capacity of policy production. For example, Lavalle et al. (2019), after analyzing the capacity of two municipalities to implement a federally induced social housing program, have argued that local administrative capacity and trajectory of institutionalization can be helpful to understand the autonomy of the municipality and policy results. Lima-Silva (2019) have also argued that local policy capacity depends on the priority of a certain policy in the governmental agenda and on the articulation among the various actors in policy-making.

Looking specifically at local governments' capacity for housing policies, a pioneer study concluded that most Brazilian municipalities lacked institutional capacity to produce this policy, whilst a small "elite" had the necessary instruments and capacity (BRASIL, 2006). This research indicated that higher administrative capacity was linked to better results in the execution of housing programs, and concluded that "improving the 
administrative capacity of Brazilian municipalities is certainly one of the main ways to reduce the high housing deficit in the country (BRASIL, 2006, p. 111) ${ }^{1 "}$.

A subsequent study by Arretche et al. (2012) analyzed the effects of the rise in investment and federal coordination on local government's capacity to produce housing policies from the 2000s on. The federal government managed to induce municipalities to improve their institutional capacity to implement housing initiatives (ARRETCHE et al, 2012; IPEA, 2011; KLINTOWITZ, 2015). In spite of this, recent research has questioned the effectiveness of the instruments frequently used as indicators of institutional capacity (RoLNIK et al, 2014; KLINTOWITZ, 2015) and argued that municipalities still have limited capacity to carry out projects, especially those related to slum upgrading (CAMPANHONI, 2016; CiRERA \& GOMES, 2013; DENALDI et al., 2016).

\section{Development of local governmental capacity for slum upgrading}

The Brazilian government's approach to slums changed over the last decades, and three main strategies of action are explored in the specialized literature and resumed in this article (REGINO, 2017; VAlladARES, 2005). The first approach emerged at the beginning of the $20^{\text {th }}$ century, simultaneously to the foundation of the first slums in Rio de Janeiro. It was based on a hygienist and authoritarian view, aiming, without success, to extinguish all slums and expel the poor from the central areas of cities (VALLADARES, 2005). At that time, there was no governmental bureaucracy - neither in the federal government nor in the municipalities - to deal permanently with this issue.

Housing became a public matter only during Getulio Vargas's government, in the 1930s. During those years, the housing deficit came to be seen as a social problem and its solution as a possible source of political legitimacy (AZEVEDO, 1988). Vargas implemented his national policy through the newly created Retirement and Pension Institutes, which were responsible for building new houses mainly to unionized workers. As a result, this government did not tackle the issue of slums, nor did it attend to the majority of poor workers, who did not have formal jobs. During the 1950s, another housing agency was created - Fundação Casa Popular, which had few quantitative results and access to housing made only for a small number of "privileged" (AzEVEDO,

\footnotetext{
1 This excerpt, as well as other excerpts and interviews that appear in the text, was translated from Portuguese into English by the authors.
} 
1988). Municipal governments and slum areas were again poorly involved in these initiatives.

In 1964, the military government, then established in the country, created the National Housing Bank (BNH) and the Housing Financial System (SFH). This bank, between 1964 and 1986, was responsible for financing almost 4.5 million housing units, but it was heavily criticized for, among other reasons, being unable to meet the housing deficit, especially in the poorer strata (AZEVEDO, 1988; KLINTOWITZ, 2015). Furthermore, BNH's actions reinforced governmental initial approach to slums, contributing to forced eviction and to the resettlement of some of their dwellers in new but peripherical houses (KLINTOWITZ, 2015).

Only in 1979 there was a slight change in the governmental strategy regarding slums. The federal government, via $\mathrm{BNH}$, started to intervene in these areas with alternative programs - such as PROFILURB and PROMORAR -, which aimed to provide financing for self-construction and rehabilitation of housing, urban infrastructure and slum upgrading. These programs, nonetheless, reached a small scale and had only a marginal insertion in the housing policies and institutional structures (DENALDI, 2003). Consequently, they did not manage to properly leverage governments' capacity to produce slum upgrading policies.

With the state fiscal crisis, in the early 1980s, the National Housing Bank was extinguished in 1986, and its functions were assigned to Caixa Econômica Federal (hereinafter CAIXA). Since then, a process of institutional instability and fragmentation of federal housing policies began, given the lack of resources and the reduced priority in the presidential agenda, which lasted until mid-2000s. During those decades of “decentralization by absence", many cities faced exponential urban growth and housing related problems became more remarkable (CARDOSO, 2007; CARDOSO \& RIBEIRO, 2002; DENALDI, 2003). Subnational governments then assumed a leading role, innovating and creating new methodologies, while the values invested by the federal government in housing were derisory (DENALDI et al, 2016). Municipal governments worked especially with slum upgrading initiatives, which had lower costs and less impact on their limited financial capacity (CARDOSO \& RIBEIRO, 2002).

Gradually, a second governmental approach to slums emerged, focusing on the upgrading of these settlements, instead of their eradication (REGINO, 2017). According to Denaldi (2003), the 1980s' slum upgrading experiences aimed to guarantee "minimal 
social rights", basic infrastructure conditions and the permanence of slums. These interventions were often based in incomplete projects, frequently made in situ. Against a democratization background, such initiatives were underpinned by growing mobilization of the population, election of mayors with social priorities and the work of militant professionals, who presented new architectural and social solutions to slums (MARICATO, 2012).

While these pioneering experiences of slum upgrading represent the inaugural development of local capacity to plan and implement this policy, it is not possible to ignore some of the criticisms that they have received. Denaldi (2003) highlights that some of these interventions, while avoiding removal at all costs, helped to consolidate inadequate housing situations. Cardoso and Ribeiro (2002) draw attention to the risk of strengthening inter-municipal asymmetry.

In the mid-1990s, in response to challenges faced in the initial upgrading initiatives, a third approach to governmental interventions in slums emerged in local and federal governments. This new approach refers to integrated upgrading, broadly characterized by the concomitant promotion of improved housing and infrastructure conditions and access by residents to other social rights (REGINO, 2017; DENALDI, 2003).

During the presidencies of Itamar Franco (1992-1994) and Fernando Henrique Cardoso (1995-2002), slum upgrading evolved from an alternative program to become part of the national housing policy. This meant federal investment through integrated slum upgrading programs such as Habitar Brasil and Habitar Brasil-BID (hereinafter HBB-BID). Although these programs reached a small scale, in many municipalities they represented the embryo of local planning and institutional structuring in the housing sector (PETRAROLLI, 2015). Consequently, subnational governments that took part in HBB-BID had more experienced technical teams and later tended to perform better in PAC-UAP (CARDOSO \& DENALDI, 2018):

\footnotetext{
We even had an expression, "this municipality had HBB"! So, the municipalities that had HBB, they really had that, is not a sufficient condition, because we had many structures that collapsed and HBBs that never ended, but at least in terms of understanding what a slum upgrading is, it was different, you had at least a half dozen technicians there who knew what the dynamics were, what the issue was (Interviewee B).
}

The election of Luis Inácio Lula da Silva (2003-2010) changed the dynamics of urban policies in terms of federal coordination. Ministry of Cities (hereinafter MCIDADES) 
was created on his first day in office. During its initial years, in a context of budgetary constraints, MCIDADES focused on its institutional structuring and on the creation of organizational capacity. It established, for example, the Cities Council and the National System of Social Interest Housing (hereinafter SNHIS).

SNHIS aimed at integrating the social housing programs of the three levels of government in a single instance, based on the principles of decentralization and social control. However, although formally established, SNHIS did not manage to consolidate itself as an effective national system of public housing policies (KLINTOWITZ, 2015; IPEA, 2011), which could generate capacity, learning and consensus between federal and subnational governments. According to Klintowitz (2015), SNHIS became a symbolic rule, giving legitimacy to federal government, but lacking effective implementation.

In Lula's second mandate, two federally induced and shared urban policies were launched - PAC-UAP and Minha Casa Minha Vida (hereinafter MCMV) - which significantly changed the resources available to municipalities and their incentives to engage with social housing. These new programs altered the scenario: indeed, they became the country's implemented housing policy, contributing to the dismantling of the SNHIS (Klintowitz, 2015; Rolnik et al, 2014)2.

PAC-UAP consolidates the third governmental approach to slum upgrading, inspired by the previous experience of HBB-BID: integrated upgrading associated with removals and replacement solutions when necessary. With this modality of the program the issue of slum upgrading definitely enters federal government's agenda, while municipal governments remain leading figures. Other actors also become more involved in the policy production, such as private companies, CAIXA, federal and local accounting offices, social/housing movements, residents in the upgraded area and other local government departments - social assistance, transportation, health etc.

It can be concluded that the development of the slum upgrading programs in Brazil points to a gradual increase of legitimacy of these interventions, as well as to a growing complexity in terms of the upgrading projects, the stakeholders involved and the skills and resources required to produce them.

\footnotetext{
${ }^{2}$ Dilma Rousseff's administration maintained these housing programs, albeit to varying degrees: PAC-UAP remained in development, but on a declining scale due to low project execution rates (DENALDI et al., 2016), while PMCMV was relaunched and expanded.
} 


\section{PAC-UAP: the program and its operationalization}

PAC was launched at the beginning of the second term of Lula's Presidency (2007-2010). It aimed, as its name implies, to accelerate economic growth, as well as to overcome infrastructure bottlenecks, increase employment and improve the living conditions of the Brazilian population. In addition to formalizing a new management and monitoring structure of its operations, PAC was given political priority (CARDOSO \& NAVARRO, 2016). Thus, a sectoral ministry, such as MCIDADES, whose public policies received the "PAC stamp" faced ambiguous consequences: on the one hand, its inclusion in a decision-making and intensive monitoring process centralized in the Presidency, and, on the other hand, as it was a priority policy, it ensured that it was free from budgetary contingencies (LOUREIRO et al., 2013).

The total amount of investments foreseen, for the period 2007-2010, was R $\$ 657.4$ billion (BRASIL, 2010, p. 30) ${ }^{3}$. This first edition of the program had five strategic axes, and one of them was called Social and Urban Infrastructure, which is where PAC-UAP was located ${ }^{4}$. With the election of Dilma Rousseff (2011-2014), a second phase of the Program, commonly called PAC 2, was launched. PAC-UAP remained in the Program, now under an axis called Minha Casa Minha Vida.

PAC - UAP constituted a new moment in the history of slum upgrading interventions in Brazil, representing an unprecedented and much higher amount of investment in this area of public policy (DENALDI et al, 2016). Between 2007 and 2009, in what was known as PAC 1, 3,133 operations for slum upgrading were contracted, corresponding to investments of $\mathrm{R} \$ 20.8$ billion; and in PAC 2, 415 new operations were contracted between 2011 and 2014, totaling R\$ 12.7 billion in 337 municipalities (BRASIL, 2014, p. 192).

As mentioned in the previous section, PAC-UAP rose in a context of accumulation of experiences on slum upgrading. The program incorporated knowledge of those initiatives related to the quality of projects, popular participation, planning and urbanistic solutions (DENALDI, 2003). Its main novelty was the increase in the volume of resources and the expansion of the scale of intervention:

\footnotetext{
${ }^{3} 1 \mathrm{U} \$=\mathrm{R} \$ 5.16$ (July $27^{\text {th }} 2020$ ).

${ }^{4}$ The five strategic axes were: (1) economic and social infrastructure; (2) stimulating credit and financing; (3) improvement of the investment environment; (4) tax exemption and improvement of the tax system; and (5) long-term fiscal measures.
} 
We had HBB-BID, so people had already worked with slum upgrading in the country. Then came FNHIS, which worked with the same slum upgrading guidelines. You see, PAC was nothing new. The novelty is the scale that the projects achieve. You go from a 1 million slum upgrading intervention to a 300 million project (LIMA-SILVA, 2014, p. 100).

PAC-UAP's operations were guided by an integrated slum upgrading approach that aimed to overcome the precarious conditions of slums from a multisectoral perspective that incorporated the "urban, housing, land, social and environmental issues" (BRASIL, 2010, p. 13). According to Balbim et al. (2013, p. 23), the interventions should focus on changing the following situations found in slums and precarious settlements:

- $\quad$ Precarious and unhealthy housing;

- $\quad$ Absence or scarce supply of essential public services;

- $\quad$ Poor access and mobility conditions;

- $\quad$ Insecurity of housing ownership and

- $\quad$ Irregularity of land and urban planning.

In terms of implementation arrangements, PAC slum upgrading interventions involved a number of actors. The Presidency of the Republic, through the Civil House, was the Central Coordinator, responsible for establishing general guidelines; validating project selection; monitoring, at a more strategic level, the evolution of operations; assisting in overcoming difficulties and fostering the improvement of management instruments and standards (BRASIL, 2010). The Ministry of Cities, as the sectoral ministry, was the Operations Manager and was responsible for monitoring the implementation and the results, establishing guidelines and operating procedures, assigning budget resources and selecting submitted proposals (BRASIL, 2010).

Caixa Econômica Federal, a national bank, was the Operator and Financial Agent, assuming the responsibility of signing the contracts after the analysis and selection by MCIDADES; promoting their budgetary and financial execution; monitoring and certifying the execution of the Terms of Commitment; keeping MCIDADES informed of the progress of operations. For Interviewee F, CAIXA was essential to enable the operationalization of the program, as the Ministry of Cities would not have "enough arms" to follow up on the execution of all PAC-UAP interventions. Still in the federal sphere, national accounting offices were identified as relevant actors, even though they were not part of the formal PAC-UAP operationalization model. These institutions were 
responsible for identifying possible irregularities during the bidding process or execution of publicly financed works.

Local governments, particularly municipalities, were the Executing Agents: they played a leading role in the definition and execution of the operations under PAC-UAP. They were responsible for identifying the area for the intervention; preparing and submitting projects for selections carried out by MCIDADES; performing the necessary work to achieve the intervention; registering and dialoguing with families in the upgraded areas; outsourcing external companies for service provision; accounting for funds transferred by the Union and maintaining the public assets generated by the investments (BRASIL, 2010).

Construction and other private companies, such as building managers and land regularization, social work and project consultancies, were hired by the Executing Agents mainly through biddings. Construction companies had control over the executive project of the intervention, and ultimately determined the materialization of the program in the territory (PATRíciO et al., 2018). Other relevant actors involved in the implementation were: the population who lived in the area and should take part on the project development; local companies (private or public) responsible for infrastructure services, such as water, electricity and sewage; and other municipal departments responsible for public services, such as education and transport.

These actors were involved in different ways according to the stages of PAC-UAP operationalization, described in Figure 1. The first stage refers to the submission and selection of slum upgrading proposals, sent by local governments and selected by the Civil House and MCIDADES, these also involved state-level agencies that grant environmental licenses as a pre-requisite for signing the contracts of the selected proposals. In the signing of contracts and the execution of bids, these same actors remain engaged, with subnational governments and CAIXA becoming more relevant. 
Figure 1 - Stages of the process of operationalization of PAC-UAP

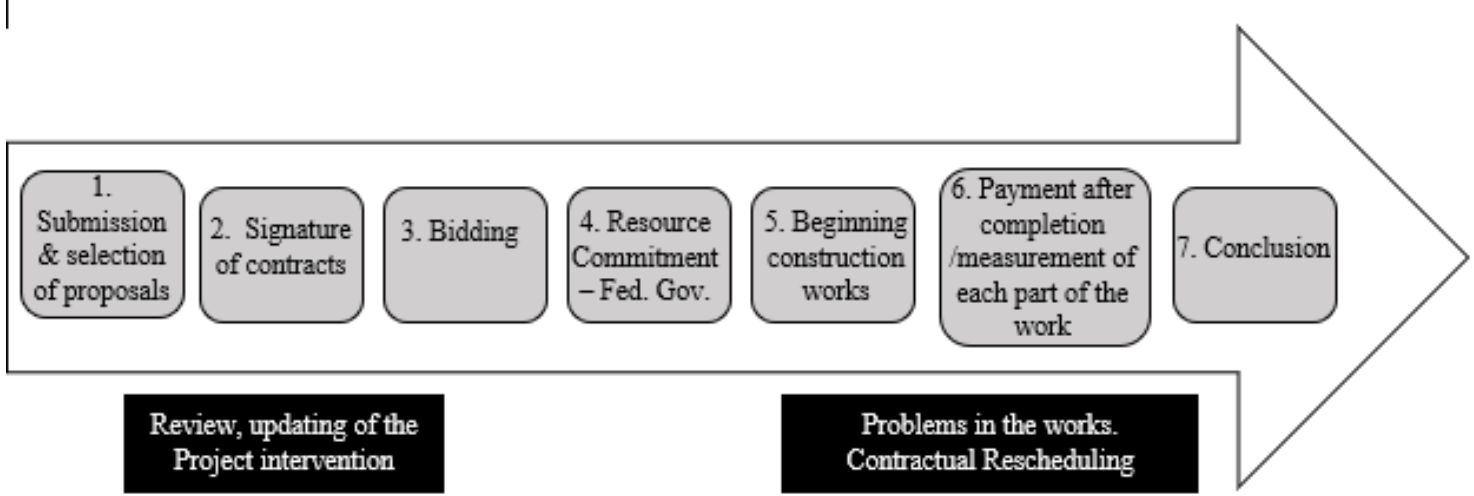

Source: Adapted from Lima-Silva (2019, p. 121).

In the following stages of operationalization - the commitment of resources, the beginning of the works, the transfers after measurements and the conclusion - the same actors are involved and others are added, such as the contracted companies and the residents of the upgraded areas. Local governments as Executing Actors and CAIXA maintain their leading role in these last stages. Through its regional agencies, CAIXA is responsible for all procedures involving the signing and management of the Terms of Commitment, as well as mediating between subnational governments and the federal government.

Black text boxes in Figure 1 refer to two key moments where implementation problems are abundant in PAC-UAP. In the first, located between the selection and bidding of operations, environmental licensing and approval of projects by CAIXA were identified as critical steps (PETRATROLLI, 2015). After signing the transfer agreement, the municipality has a deadline to present the complete documentation and comply with the norms and guidelines, and CAIXA only authorized the bidding of the works when the intervention proposal "matured" (Interviewee G). However, many Executing Agents had problems in the previous environmental licensing and presented incomplete, outdated and misaligned intervention projects, affecting the signing of the contract and the effective commencement of works. According to Denaldi et al (2016), the initial licensing, evaluation, contracting and bidding processes are always lengthy and it is common that during this time the conditions and characteristics of the settlements change.

The second problematic moment, between the beginning of the works and its conclusion, covers three actors directly involved in the implementation of operations: the 
Executing Agent (municipality), CAIXA and the contractors. This moment includes situations in which the Executing Agents need to reconcile the proposals approved by CAIXA with the unforeseen events and the constant transformation of the territories in slums. When there are measurement problems, it is common for the Operator Agent to block the payment of services that do not correspond exactly to the approved operation. This situation can only be resolved by contractual reprogramming, which are administrative procedures that modify the approved project or the anticipated quantities of materials and services. However, Petrarolli (2015) identifies that the reprogramming initiatives, complex and long procedures, can last up to six months.

The consequences of these two troublesome moments in the implementation of PAC-UAP are abundantly described in the literature. They include delays and interruptions, increasing the complexity of a work that has to deal with the constant transformation of the slums, and, as a result, the changing scope of the upgrading project and the growing insufficiency of the agreed investments in the Term Commitment. This last point also stems from the loss of the real value of the budget, as the Union does not readjust the onlending amounts contracted and the price of materials follows a fixed national system of prices, which, according to several reports, does not cover the actual costs of materials 5 .

\section{PAC-UAP: analyzing its production capacity}

Despite the unprecedented amount of resources invested in slum upgrading and the intensive monitoring system, many of PAC-UAP's operations had implementation problems. Both the specialized literature and the actors involved with PAC-UAP highlighted the low execution rates and the difficulties of operationalizing this subprogram (CAMPANHONI, 2016; DenAldi et al., 2014, 2016; PeTRAROLLI, 2015; Interviewee A, B, F, G).

In fact, as depicted in Table 1, which analyses the financial execution of the first phase of PAC-UAP operations led by municipal governments, less than $25 \%$ of them

\footnotetext{
${ }^{5}$ The National Construction Costs and Indexes Survey System (SINAPI) is an official price reference source for the budgeting of engineering works and services, contracted and executed with Union resources. In PAC-UAP, CAIXA used Sinapi as a cost reference, and only paid up to the price limit established in this system, which, according to several respondents, often did not cover the actual costs of materials. The price difference had to be absorbed by the construction company or the municipality.
} 
were concluded by 2017 . The average execution rate in the contracts between municipalities and federal government reached $65 \%$, and merely $32 \%$ of the contracts had reached more than 95\% of implementation in December 2017.

Table 1 - Financial execution of PAC-UAP

\begin{tabular}{lcc}
\hline Financial execution & Number of contracts & Percentage \\
\hline Concluded & 157 & 23,64 \\
\hline More than 75\% & 175 & 26,36 \\
\hline Between 50 and 75\% & 113 & 17,02 \\
\hline Between 25 and 50\% & 115 & 17,32 \\
\hline Up to 25\% & 99 & 14,91 \\
\hline Unitiated works & 5 & 0,75 \\
\hline Total & 664 & 100,00 \\
\hline
\end{tabular}

Source: Adapted from Lima-Silva (2019, p. 126). Data analyzed include all Terms of Commitment for the execution of slum upgrading works under PAC and managed by National Housing Secretary, signed between 2007 and December 2017.

Several research papers have been dedicated to unveiling the slum upgrading operations within PAC and its low results (CAMPANHONI, 2016; CARDOSO \& DENALDI, 2018; Denaldi et al., 2016; Denaldi \& Ferrara, 2017; Petrarolli, 2015; Regino, 2017). The argument that justifies these results often lies on the limited capacity of local governments, affecting their ability to elaborate slum upgrading projects and to manage their execution (DENALDi et al., 2016; PETRAROLLI, 2015; CAMPANHONI, 2016; CiRERA \& GOMES, 2013). This reasoning is demonstrated below, extracted from an interview with a public manager at the Ministry of Cities:

The fact is that, considering institutional capacity installed in municipalities today, you have much trouble executing the available money. Our execution in PAC-UAP is $1 \%$ per month, it is desperate (LIMA-SILVA, 2014, p. 101).

These researches have also identified general obstacles to the implementation of this program, such as the rigidity in contracting and measuring works with the Operator Agent, outdated or incomplete intervention projects, and the emergence of unforeseen problems. Denaldi et al. (2016) and Petrarolli (2015) suggest additional problems, more related to local realities, through the triad "complexity of intervention, project quality and changing territory". Indeed, a refined look into PAC-UAP indicates that other elements 
should be incorporated to generate a more accurate understanding of its production capacity. Wu et al (2015) provide an interesting analytical model to carry this task out. They define policy capacity as a set of analytical, operational and political resources and competences necessary for developing policy functions, being applied in different levels - individual, organizational and systemic. Their nested-model of capacity is useful, as it allows to analyze the involvement and the skills of different stakeholders and the use of resources for policy production. Table 2 presents a proposal of the relevant abilities and resources for producing PAC-UAP.

Table 2 - Abilities and resources for producing PAC-UAP

\begin{tabular}{l|l|l|l}
\hline & Individual resources & $\begin{array}{l}\text { Organizational } \\
\text { resources }\end{array}$ & Systemic resources \\
\hline $\begin{array}{l}\text { Analytical } \\
\text { skills }\end{array}$ & $\begin{array}{l}\text { Staff/public servers from } \\
\text { organizations involved with } \\
\text { PAC-UAP with technical } \\
\text { abilities coherent to the policy's } \\
\text { specificity }\end{array}$ & $\begin{array}{l}\text { Availability of skilled } \\
\text { professionals in the } \\
\text { various organizations } \\
\text { involved }\end{array}$ & $\begin{array}{l}\text { Professionals' technical } \\
\text { skills recognized } \\
\text { within agencies/society }\end{array}$ \\
\hline $\begin{array}{l}\text { Operational } \\
\text { skills }\end{array}$ & $\begin{array}{l}\text { Municipal bureaucrats with } \\
\text { autonomy and managerial ability, } \\
\text { acting as the node of a network of } \\
\text { operations }\end{array}$ & $\begin{array}{l}\text { Coordination among } \\
\text { different agencies in } \\
\text { the policy-making for } \\
\text { effective slum } \\
\text { upgrading policies }\end{array}$ & $\begin{array}{l}\text { Level of public support } \\
\text { of organizations to } \\
\text { develop policies and } \\
\text { solve problems }\end{array}$ \\
\hline $\begin{array}{l}\text { Political } \\
\text { skills }\end{array}$ & $\begin{array}{l}\text { Skilled municipal } \\
\text { bureaucrats/consultants that align } \\
\text { interests and minimize opposition }\end{array}$ & $\begin{array}{l}\text { All actors aligned to } \\
\text { achieve the program's } \\
\text { results }\end{array}$ & $\begin{array}{l}\text { Public legitimacy and } \\
\text { trust of PAC-UAP's } \\
\text { interventions }\end{array}$ \\
\hline
\end{tabular}

Source: Elaborated by the authors, based on Wu et al (2015).

When combining the information from the above table and from the interviews, it is possible to make additional considerations on PAC-UAP's capacity. First, low municipal capacity is an important element and relates mainly to the analytical and operational skills in the individual dimension. A common argument in the literature is that many municipal governments had reduced or non-qualified technical teams and lacked the experience and ability to properly plan, design and implement PAC-UAP interventions (CAMPANHONI, 2016; Denaldi et al., 2016; Denaldi \& FerRara, 2017). This is frequently justified as a consequence of constrained municipal budgets and decades of scarce federal investments in slum upgrading, as exemplified below: 
You never prepare a public policy without clear expectation of resources. The resources become available and then people start preparing projects. So there really wasn't updated and complete slum upgrading projects after 20 years without investments, there were no projects in the pipeline. Therefore, the first selection of projects within PAC was made with incipient projects, with proposals, with ideas... (Interviewee B).

Nevertheless, one size doesn't fit all and this argument is not entirely applicable in every municipal context. There are considerable differences in technical and political individual skills existent in municipalities and they seem to have a relationship with policy results. The two municipalities analyzed exemplify this: in the implementation of PAC-UAP, São Bernardo do Campo, which had higher rates of financial execution, prioritized the interventions in this subprogram, carried out civil service examination and hired professionals with previous work on slum upgrading (REGINO, 2017), while Santo André, due to political intermittence, gradually lost very experienced and skilled professionals, as this excerpt demonstrates:

\begin{abstract}
It is important to have a technical staff compatible, in terms of number of professionals, with what you will face, the set of works, of projects. What happened in Santo André, the team was very reduced in view of the task. The workload increased with PAC, with PAC came resources and, therefore, the work and the number of upgrading increased and I reduced the team. So, of course, I lose part of my institutional capacity. (Interviewee D)
\end{abstract}

In spite of these variances, it is feasible to argue that even municipalities that had previous experience and analytical-operational capacity on slum upgrading faced problems related to the planning and execution of interventions. Therefore, the issue with PAC-UAP production seems to be more related to using the available municipal resources and skills to overcome unavoidable implementation problems. This common challenge can be partially understood by the difficulty of reconciling the timing of government producing a project, signing the Term of Commitment, bidding and starting the works and the timing of people, particularly the constant transformation of slums (CARDOSO \& DENALDI, 2018), as described below:

In the case of slums there is a difficulty. As the urban dynamics are very fast, I can't make a project, detail the project, bid the project, start the execution ... when one starts the execution, the reality is different (Interviewee E)

On the other hand, PAC-UAP was as a rare opportunity for many municipalities to access federal resources for large scale slum upgrading and this had positive impact on some local governments' political and analytical capacity (PETRAROLLI, 2015). 
Furthermore, it is relevant to mention that individual resources were also challenges to the other actors involved in PAC-UAP's production. The specialized literature and the interviews point that relevant stakeholders, particularly from CAIXA and external accounting offices, had very little knowledge on slum upgrading and often made requirements that were reasonable from a financial or managerial point of view, but very distant from the reality of these interventions (Interviewee D; PETRAROLLI, 2015; CARdoso \& Denaldi, 2018).

Secondly, another recurrent point in the PAC-UAP literature relates to the difficulty of inter-organizational management, including the rigidity of the contracting and operationalization model (CAMPANHONI, 2016; CARDOSO \& DENALDI, 2018; Petrarolli, 2015; Regino, 2017). Relating it to the analytical model of Wu et al. (2015), this point resembles the operational dimension of capacity at its three levels (individual, organizational and systemic), illuminating problems related to coordination between different state and non-state actors involved in the operationalization of the subprogram. Commonly mentioned operationalization problems were related to excessive oversight by external accounting offices and to immoderate bureaucratic (and discretionary) monitoring by CAIXA. According to a public manager:

\begin{abstract}
As the slum upgrading interventions evolved and the resources increased, so did the control and the fear of the bureaucrats who were involved in the transfer and control of these resources. And this started to slow down the execution of the projects a lot. And we also had many problems with the discretion of CAIXA's employees. They analyzed the projects, and when something was not very explicit in the norms, the technician often decided to take the decision on his own, saying "I will not approve because of this, because of that", even when the project was correct (Interviewee C).
\end{abstract}

Recent research identified that CAIXA has adopted stricter procedures for supervision and management of works under PAC-UAP to meet the recommendations of the accounting offices, such as the Federal General Accounting Office or Tribunal de Contas da União (TCU) (CAMPAnhoni, 2016; Petrarolli, 2015). Similarly, Interviewee D stated that many times this extra requirement of CAIXA had to do with the recommendation of accounting offices, arguing that these organs were unaware of the phenomenon and the nature of slum interventions.

Similar coordination problems were found in the relationship between municipal governments and residents of the upgraded areas and social movements, particularly when the interventions involved evictions or replacements, as well as with other local 
departments in charge of infrastructure, environmental licensing and land regularization processes. Furthermore, subnational governments had problems with private construction companies hired through bidding processes: many of these companies had little experience with slum upgrading and low floating capital, and ended up in bankruptcy or terminating the contracts in the middle of the works (CAMPANHONI, 2016).

Thirdly, organizational factors also contributed to minimizing PAC-UAP capacity. Besides the operational-organizational elements previously mentioned, some states, especially those in the North and Northeast of the country, lacked specialized professionals to perform the demanded services, reducing the subprogram's analyticalorganizational capacity. Due to the unforeseen investment in slum upgrading, not only could municipalities not respond properly, but neither did local companies and professionals. Therefore, according to one of the interviewees from MCIDADES, referring to a conversation with a public manager from the Northeast:

\begin{abstract}
In one of these talks [about the difficulties in implementation], he asked: do you know how many pachymetry experts there are in the whole Northeast? How many offices are there? The region only has two specialized offices, and they are loaded with work, because there are sanitation works, the transposition of the São Francisco River... There are two huge projects, and these offices only have one open spot in their agenda in four months from now, there's nothing I can do. (...) We have a distribution of professionals, skills that is very unequal, both in the public sector but also in the private sector (Interviewee A).
\end{abstract}

Fourthly, the framework also made evident the fragility of PAC-UAP in terms of systemic-political capacity. Shortly after its launch, given its feeble execution rates, PAC-UAP and the theme of slum upgrading lost systemic legitimacy (WU et al, 2015), and the program was unable to remain a priority in the national agenda (KLINTOWITZ, 2015). This can also be understood in light of the emergence of MCMV, which provided results much faster than PAC-UAP: between 2006 and 2014, the former executed almost three times more resources than the latter (KLINTOWITZ, 2015). These results can be better comprehended by analyses of implementation arrangements. In PAC-UAP subnational governments assume responsibility for the operations, being accountable to a federal management system characterized by bureaucratic procedures and intensive monitoring. MCMV, on the contrary, shifts the participation of municipalities to the background, simplifies operationalization and accountability, and expands the participation of the private sector, with a view to making policy implementation more agile. As a result, it quickly became a success in terms of results. 
My House My Life brings a problem, which is his wonderful hiring model. By the way, we joke that it is the magic tube, which enters the public money, the private money comes from the other side, because it dispenses all these bidding issues, Sinap and I don't know what, which makes the model so slow (Interviewee B).

Finally, this study suggests a new set of explanations to understand a policy's capacity, not entirely prescribed in Wu et al.'s analytical framework (2015). They relate to factors endogenous to the policy. Recent research has emphasized the need to recognize the ambiguity of the term slum upgrading - which can refer, for example, to integrated slum upgrading or to slum eradication -, the multiplicity of the territories to which it refers, as well as the variety of possible interventions, with different characteristics, costs and results (MORETTI et al, 2009). Therefore, to best comprehend PAC-UAP operations and its implementation results it is necessary to keep in mind that this is an "umbrella" program, with varied levels of technical and social difficulties, and to consider the characteristics of the territories and the planned interventions (CARDOSO \& Denaldi, 2018; DenAldi et al., 2016). In this regard, one of the interviewees mentioned that:

And sometimes a work that has low execution ... you have to see, it is one thing to run water and sewage in a city, in a precarious settlement of the countryside, where the street is there, it is an easier thing. Another thing is to do one of these works that you start moving a retaining wall that falls, which would not fall. So, then, it's not just institutional capacity (Interviewee D).

Additionally, studying slum upgrading requires the recognition of the existence of unforeseen events and the constant transformation of the territories (CARDOSO \& DENALDI, 2018). This produces an evident mismatch between the informal settlements' time and the time of government to formulate and implement these operations. Slum upgrading projects, which already take longer due to the difficulties associated with the diagnosis and planning in informally occupied areas, often quickly become obsolete.

These features of slum upgrading policies are not adequately taken into consideration in the current model for contracting and payment in PAC-UAP, which emphasizes bureaucratic procedures. The design of PAC-UAP privileges such respect for the rules and procedures of the contracted operations that it generates unreliable situations, where minor changes are rejected or require contractual reprogramming and the planning of interventions quickly become disused if they are to follow strictly all the small items of the contracts. 
Table 3 provides an empirical overview of PAC-UAP's capacity. In general, this subprogram had low capacity. It had problems related to scarce individual and organizational resources, impacting on the ability of local governments to design and implement slum upgrading operations. However, PAC-UAP also faced political and systemic barriers, as well as problems caused by the mismatch between the rules of the subprogram and the characteristics of the policy, which negatively affected its production capacity.

Table 3 - Empirical analysis of PAC-UAP's capacity

\begin{tabular}{|c|c|c|c|}
\hline & Individual resources & Organizational resources & Systemic resources \\
\hline $\begin{array}{l}\text { Analytical } \\
\text { skills }\end{array}$ & $\begin{array}{l}\text { Municipalities' staff with } \\
\text { varied capacity, professionals } \\
\text { from other agencies with } \\
\text { reduced experience with slum } \\
\text { upgrading. }\end{array}$ & $\begin{array}{l}\text { Submission and selection of } \\
\text { low-quality projects } \\
\text { Low in some parts of the } \\
\text { country: unavailability of } \\
\text { skilled professionals. }\end{array}$ & $\begin{array}{l}\text { Low trust on municipal } \\
\text { professionals' capacity }\end{array}$ \\
\hline $\begin{array}{l}\text { Operational } \\
\text { skills }\end{array}$ & $\begin{array}{l}\text { Reduced municipal staff to } \\
\text { handle complex processes: } \\
\text { project design and management, } \\
\text { reprogramming, licensing, } \\
\text { accountability. }\end{array}$ & $\begin{array}{l}\text { Coordination problems } \\
\text { between agencies and with } \\
\text { companies. } \\
\text { Bureaucratic control. }\end{array}$ & $\begin{array}{l}\text { Action from control } \\
\text { agencies: strong } \\
\text { supervision, negative } \\
\text { effects. }\end{array}$ \\
\hline $\begin{array}{l}\text { Political } \\
\text { skills }\end{array}$ & $\begin{array}{l}\text { Communication problems with } \\
\text { residents, mainly in removals. }\end{array}$ & $\begin{array}{l}\text { Municipalities gradually lost } \\
\text { federal government support. }\end{array}$ & $\begin{array}{l}\text { Gradual loss of public } \\
\text { legitimacy and trust, } \\
\text { impacting on PAC's } \\
\text { priority on the agenda. }\end{array}$ \\
\hline
\end{tabular}

Source: Elaborated by the authors, based on Wu et al. (2015).

\section{Final considerations}

Considering that the implementation of many public policies is currently based on decentralization and involves different governmental and non-governmental actors, this article aimed to advance understanding on the capacity to produce shared and federally induced policies in federations marked by heterogeneity among its subnational governments. Empirically, the article analyzed Brazilian slum upgrading interventions within PAC, a federal program that leveraged investment on this policy sector and faced many implementation problems.

The present study corroborated the commonly spread view that, in federations with heterogeneous capacity among local governments, many municipalities lack abilities 
and resources to properly implement shared urban policies. Even when they have sufficient federal financing, these local governments often face unsurmountable challenges to operationalize the interventions and cannot reach the agreed outcomes.

Notwithstanding, the detailed analysis of PAC-UAP's capacity showed that a more accurate comprehension of the results of a shared and federally induced policy implementation can only be achieved if other factors are taken into careful consideration. First of all, based on the application of Wu et al. (2015)'s analytical model to PAC-UAP, we suggest that it is necessary to go beyond the argument that directly links feeble policy implementation results to local government's reduced capacity. In this research, São Bernardo do Campo and Santo André, municipalities with a trajectory on slum upgrading and varied capacity on terms of analytical and operational skills faced considerable implementation problems. Therefore, based on our findings, we recommend that future studies on policy capacity should not look only at local administrative capacity, but take into attentive consideration the technical and relational capacity of other actors involved in this policy-making and the organizational and systemic resources.

Secondly, we argue that the general concept of state capacity has analytical validity. Notwithstanding, resuming to Wu et al. (2015)'s work, we assume that this debate has more explanatory potential when it is viewed in the realms of specific areas of public policies. In PAC-UAP, the implementation challenges became more acute due to the mismatch between the norms of the Program and endogenous characteristics of slum upgrading interventions. The opposition between the formal and bureaucratic model of implementation and the reality of slums, which are constantly changing and demand flexible and creative interventions, represented, in some cases, deadlocks and a serious challenge to the achievement of results. Future research can explore this finding deeper, particularly how specific characteristic of policies relate to this general framework of policy capacity.

The article also suggests that local governments' capacity to produce slum upgrading interventions seems to have evolved accordingly to historical contexts. In a scenario of scarce federal investment in housing, despite innovative and small-scale initiatives by local governments in the decades of 1980 and 1990, most municipalities lacked staff, information resources and high-quality projects for intervening in slums. The launching of a federal program has helped them to insert this issue on the local political agenda, contributing to the development of municipalities' capacity. This indicates that 
PAC-UAP may have supported a brief trend of growing local governments' capacity for implementing housing policy, as already identified by Arretche et al. (2012).

Finally, it is worth mentioning that the gradual loss of PAC-UAPs' political legitimacy affected local level capacity-building for slum upgrading initiatives and the subprograms' general capacity, gradually losing steering abilities. If excessive bureaucratic rules and monitoring constitute per se challenges for implementation, particularly to the municipalities with less experience and capacity for producing urban policies, they become even more challenging in contexts of low legitimacy, in which subnational governments have lost trust as implementing partners. This leaves them with less leverage to influence the program, promote learning and adaptation that best fits the shared policy to local actors' needs. This process of lessening legitimacy of slum upgrading in the governmental agenda began around 2009 and it is reinforced today, bringing the peril of gradual dismantling of the capacities recently incentivized and reshaped.

\section{References}

ABRUCIO, F. L. (2005). A coordenação federativa no Brasil: A experiência do período FHC e os desafios do governo Lula. Revista de Sociologia e Política, n. 24, p. 41-67.

ARReTCHe, M. (2012). Democracia, federalismo e centralização no Brasil. Rio de Janeiro: Editora FGV/Fiocruz.

et al. (2012). Capacidades administrativas dos municípios brasileiros para a política habitacional. Brasília: Ministério das Cidades.

AZEVEDO, S. (1988). Vinte e dois anos de política de habitação popular (1964-1986): Criação, trajetória e extinção do BNH. Revista de Administração Pública, Rio de Janeiro, v. 22, n. 4, p. 107-119.

BALBIM, R.; KRAUSE, C. BECKER, M. F.; NETO, V.C. L.; CASSIOLATO, M. M.; ANDRADE, C. C. (2013). Metodologia de avaliação de resultados: o caso das intervenções do PAC Urbanização de Favelas. Texto para discussão № 1.903. Instituto de Pesquisa Econômica Aplicada (IPEA), Brasília.

BICHIR, R. M. (2011). Mecanismos federais de coordenação de políticas sociais e capacidades institucionais locais: O caso do Programa Bolsa Família. Tese (Doutorado em Ciência Política). Instituto de Estudos Sociais e Políticos da Universidade do Estado do Rio de Janeiro.

BRASIL. (2006). Capacidades administrativas, déficit e efetividade na política habitacional. Brasília: Ministério das Cidades, SNH; CEM/CEBRAP.

(2010). Urbanização de favelas: A experiência do PAC. Ministério das Cidades,

Secretaria Nacional de Habitação. Brasília.

REVISTA DO SERVIÇO PÚBLICO | Brasília 71 (special) 116-143 Oct. 2020 
(2014). $11^{\circ}$ Balanço do PAC2 - set/dez 2014. Disponível em http://www.pac.gov.br/pub/up/pac/11/PAC11_MinhaCasaMinhaVida.pdf. Acesso em: 28/08/2017.

CAMPANHONI, A. (2016). Implementação da política federal de habitação para assentamentos precários: gestão municipal e os entraves na execução das intervenções. Revista Serviço Público, Brasília, 67 (2), p. 227-248, Abril/Junho.

CARdoso, A. L. \& DenALDI, R. (orgs.). (2018). Urbanização de favelas no Brasil: Um balanço preliminar do PAC. 1. ed. Rio de Janeiro: Letra Capital.

(2007). Avanços e desafios na experiência brasileira de

urbanização de favelas. Cadernos Metrópole, n. 17, p. 219-240, $1^{\circ}$ sem.

CARdoso, A. L. \& RIBEIRO, L. C. Q. (2002). A municipalização das políticas habitacionais: Uma avaliação recente (1993-1996). Relatório final, Parte I. Rio de Janeiro: IPPUR/FASE.

CARdoso, A. L. R. \& Marenco, A. (2019). Qualidade burocrática e performance estatal: Desvendando a caixa preta do município. Administração Pública e Gestão Social, 11 (4), setembro-dezembro.

CARdoso, J. C. \& Navarro, C. A. (2016). O Brasil na encruzilhada: Política, planejamento e investimentos na experiência recente (2007-2014) do PAC: ruptura democrática e estagnação econômica. Disponível em: http://plataformapoliticasocial.com.br/wpcontent/uploads/2016/12/Rela\%C3\%A7\%C3\%A3o-de-Produtos-Licen\%C3\%A7a-2016-4PAC-VF-Publica\%C3\%A7\%C3\%A3o.pdf

CiRerA, M. \& GoMes, R. P. (2013). PAC - Urbanização de assentamentos precários: Os limites da ação municipal na região do Grande $\mathrm{ABC}$ Paulista. Serviço Social e Realidade, Franca, v. 22, n. 2.

CINGOLANI, L. (2013). The state of State capacity: A review of concepts, evidence and measures. Working Paper, n. 53. Maastricht: UNU-MERIT.

DENALDI, R. (2003). Políticas de urbanização de favelas: Evolução e impasses. Tese (doutorado) - Faculdade de Arquitetura e Urbanismo da Universidade de São Paulo.

DENALDI, R. \& FERRARA, L. N. (2017). Urbanização de favelas na região do ABC Paulista, Brasil: um balanço das intervenções recentes e seus desafios. In: CIHEL - CONGRESSO INTERNACIONAL DA HABITAÇÃO NO ESPAÇO LUSÓFONO, 4., 2017, Portugal. Anais [...]. Portugal.

Denaldi, R.; Moretti, R.S; Nogueira, F.; Paiva, C.; \& Petrarolli, J. (2016). Urbanização de favelas na Região do $\mathrm{ABC}$ no âmbito do Programa de Aceleração do Crescimento-Urbanização de Assentamentos Precários. Cadernos Metrópole (PUCSP), v. 18, p. 101-118.

DENALDI, R.; AKAISHI, A. G.; PAIVA, C.; NOGUEIRA, F. R.; PETRAROLLI, J.; MORETTI, R. (2014). O Programa de Aceleração do Crescimento - Urbanização de Assentamentos Precários (PAC-UAP) na região do ABC: Características e Execução. In: Seminário Nacional sobre Urbanização de Favelas - UrbFavela, I., São Bernardo do Campo, 2014. Anais [...]. São Bernardo do Campo, SP.

FARAH, M. (2001). Parcerias, novos arranjos institucionais e políticas públicas no nível local de governo. Revista de Administração Pública, Rio de Janeiro, v. 35, n. 1, pp. 119-144, Jan./Fev.. 
Gomide, A. A.; PereirA, A. K.; \& Machado, R. (2017). Apresentação: O conceito de capacidade estatal e a pesquisa científica. Soc. e Cult., Goiânia, v. 20, n. 1, p. 3-12.

GRIN, E. (2016). Rotas federativas para a promoção das capacidades estatais municipais: Uma análise da experiência brasileira. Tese (Doutorado em Administração Pública e Governo) - Escola de Administração de Empresas de São Paulo da Faculdade Getulio Vargas.

IPEA. (2011). O planejamento da habitação de interesse social no Brasil: Desafios e perspectivas. Comunicados do IPEA, n. 188.

KLINTOWITZ, D. (2015). Entre a Reforma Urbana e a Reforma Imobiliária: A Coordenação de Interesses na política habitacional brasileira nos anos 2000. Tese (Doutorado em Administração Pública e Governo) - Escola de Administração de Empresas de São Paulo da Faculdade Getulio Vargas.

KOCHER, M. (2010). State capacity as a conceptual variable. Yale Journal of International Affairs, $5(2)$.

LaVAlle, A. G.; Rodrigues, M.; \& Guicheney, H. (2019). Agência local e indução federal: A operação da política municipal de habitação em Recife e Curitiba. Revista de Sociologia e Política, v. 27, n. 71.

LiMA-SILVA, F. (2014). Coordenação governamental no presidencialismo de coalizão brasileiro: Estudo de caso sobre o Ministério das Cidades no Governo Lula. Dissertação (Mestrado em Administração Pública e Governo) - Escola de Administração de Empresas de São Paulo da Faculdade Getúlio Vargas.

Lima-Silva, F. (2019). Prioridade política e capacidade burocrática: A implementação do PAC-Urbanização de Assentamentos Precários. Tese (Doutorado em Administração Pública e Governo) - Escola de Administração de Empresas de São Paulo da Faculdade Getúlio Vargas.

LiNDVALL, J. \& TEORELl, J. (2016). State capacity as power: A Conceptual Framework. STANCE Working Paper Series, v. 2016, n. 1. Lund: Department of Political Science, Lund University.

LOUREIRO, M. R.; MACARIO, V.; \& GUERRA, P. (2013). Democracia, arenas decisórias e políticas públicas: o Programa Minha Casa Minha Vida. Texto para discussão 1886. Instituto de Pesquisa Econômica Aplicada (IPEA), Rio de Janeiro, outubro.

MARICATO, E. (2012). O impasse da política urbana no Brasil. 2. ed. Petrópolis: Editora Vozes.

MoretTi, R. S.; COMARU, F.; \& SAMORA, P. R. (2009). Definição das diretrizes de intervenção - operacionalização das intervenções integradas em assentamentos precários. In: DENALDI, R. (org.). Ações Integradas de Urbanização de Assentamentos Precários. 1. ed. Brasília/São Paulo: Ministério das Cidades/Aliança das Cidades. v. 1, p. 203-234.

PAINTER, M. \& PIERRE, J. (2005). Unpacking policy capacity: Issues and themes. In: PAINTER, M. \& PIERre, J. (eds). Challenges to State Policy Capacity. Palgrave Macmillan, London.

PAtricio, N. A.; CARdoso, A. L.; YASSU, A. (2018). A urbanização de favelas na política habitacional brasileira: a experiência do Rio de Janeiro. In: SEMINÁRIO LATINOAMERICANO SOBRE ASSENTAMIENTOS POPULARES, 2018, Buenos Aires. Anais [...]. Buenos Aires, Abril. 
Petrarolli, J. (2015). O tempo nas urbanizações de favelas. Contratação e execução de obras do PAC no Grande ABC. Dissertação (Mestrado). Pós-graduação em Planejamento e Gestão do Território da Universidade Federal do ABC.

REGINO, T. M. (2017). Direito à moradia, intervenção em favelas e deslocamento involuntário de famílias - Conflitos e desafios para as políticas públicas. Dissertação (Mestrado). Pósgraduação em Planejamento e Gestão do Território da Universidade Federal do ABC .

RolNIK, R.; KlinTOWITZ, D.; \& IACOVINI, R. F. G. (2014). Habitação em municípios paulistas: Construir políticas ou "rodar" programas? Revista Brasileira de Estudos Urbanos e Regionais, v. 16, n. 2, p. 149-165.

SAGUIN, K; RAMESH, N. (2018). Decentralization, education governance and policy capacity: Pre-School reforms in the Philippines. International Workshop on Public Policy, International Public Policy Association (IPPA), Pittsburgh, PA, 2018.

SATYRo, N. G. D.; Cunha, E. S. M.; CAmpos, J. (2016). Análise espacial da burocracia da assistência social nos municípios brasileiros: Notas para uma reflexão sobre a capacidade de implementação dessa política. Opin. Publica [online], vol.22, n.2, pp.286-317.

SouZA, C. (2002). Brazil: The prospects of a center-constraining federation in a fragmented polity. Publius: The Journal of Federalism, v. 32, n. 2, p. 23-48, janeiro.

StAKe, R. E. (1998). Case studies. In: DenZin, N. K.; LinColn, Y. S. (Eds.). Strategies of qualitative inquiry. Sage Publications: California.

STOKER, G. (2011). Was local governance such a good idea? A global comparative perspective. Public Administration, Vol. 89, No. 1, pp. 15- 31.

VAlladARES, L. P. (2005). A invenção da favela: Do mito de origem a favela. com. Rio de Janeiro: Editora FGV.

Wu, X; RAMESh, M.; \& Howlett, M. (2015). Policy capacity: A conceptual framework for understanding policy competences and capabilities. Policy and Society, v. 34, p. 165-171.

\section{Fernanda Lima-Silva}

iD https://orcid.org/0000-0003-4838-7075

PhD. in Public Administration and Government from the Fundação Getulio Vargas Escola de Administração de Empresas de São Paulo (FGV EAESP). Postdoctoral researcher at Centro de Administração Pública e Governo (Ceapg) in FGV EAESP. E-mail: fernanda.silva@fgv.br

\section{Maria Rita Loureiro}

iD https://orcid.org/0000-0003-3129-4956

Full professor of Public Administration and government of FGV/SP and retired professor from FAculty of Economics and Management of University of São Paulo (FEA/USP). Master and Doctorate in Sociology from the University of São Paulo, with a post-doctorate in Sociology from the École des Hautes Études en Sciences Sociales de Paris and in Political Science from the New York Univers.

E-mail: marita.loureiro@gmail.com 